\title{
A Comparative Study between Response Surface Methodology and Genetic Algorithm in Optimization and Extraction of Leaf Protein Concentrate from Diplazium esculentum of Assam
}

\author{
Jayabrata Saha, Sourav Chakraborty and Sankar Chandra Deka*
}

\author{
Department of Food Engineering and Technology, Tezpur University, Napaam, Sonitpur, \\ Assam-784028, India
}

\begin{abstract}
Fern is a seedless vascular plant that reproduces via spores and has various usefulness. This study was carried out to optimize the conditions of leaf protein concentrate extraction using ultrasound from defatted fern type Diplazium esculentum. The extraction of defatted fern protein was conducted using ultrasound. Rotatable central composite design (RCCD) of response surface methodology was used for identification of the best condition and extraction yield optimization. An attempt with genetic algorithm optimization was also carried out and revealed that optimized results were of highest desirability as compared to response surface methodology. The final optimum results, by using genetic algorithm was observed to be 21.12 min of sonication time, $56.88^{\circ} \mathrm{C}$ temperature, $7.59 \mathrm{pH}$ and $66.2 \mathrm{ml}$ of solvent for an optimum protein yield of $33.79 \%$ where desirability value was 1.00 . UHPLC analysis of the sample revealed the presence of all the essential amino acids, except tryptophan.
\end{abstract}

Keywords: Leaf protein concentrate, Diplazium esculentum, GA, Optimization, Response surface methodology, Genetic algorithm.

\section{INTRODUCTION}

Diplazium esculentum is one of the most commonly consumed edible fern found throughout Asia and Oceania. It is known as Pucuk paku in Malaysia, Paco in the Philippines, Dhekia in Assam, Dhenkir shaak in Bengali and Linguda in Northern India, referring to the curled fronds [1]. In Thailand it is known as Phak khut. It is reported to have mild amounts of fern toxins but no major toxic effects were recorded [2]. This plant has higher amount of bioactive compounds such as antioxidants, vitamins, proteins, carbohydrates and lipids [3]. Studies of plant proteins, as a nonconventional source has been on the increase, due to the new challenges of providing adequate protein for an expanding world population [4]. The world is coming to recognize the grim truth that ultimately the population growth will outstrip food suppliers with apocalyptic results. About 36 million people die every year as a result of hunger on contrary it has been reported, that amino acid compositions of leaf protein concentrate (LPC) is as good or as better than that of many common food stuffs which can solve this major problems in the developing world [5-7]. Proteins are indiscriminating constituent in human diet to sustain human development production of protein is a must. Attempts are being made to develop techniques to evaluate various sources of unconventional protein sources which in turn can diminish protein calorie

*Address correspondence to this author at the Department of Food Engineering and Technology, Tezpur University, Napaam, India, Sonitpur, Assam-784028, India; Fax: +91 3712 267006; E-mail: sankar@tezu.ernet.in malnutrition [6]. Proteins play an important role in food processing and food product development, as its functional properties influence consumer acceptability. Both animal and plant proteins are used commercially as functional ingredients. Plant proteins are the most abundant in the world. A number of vegetable proteins have been tried to incorporate in various food products as well as functional and nutritional ingredients [7].

Application of ultrasound in food industry is attracting much attention nowadays [8]. The objective of this study was to optimize the condition of ultrasound assisted extraction technology of proteins from Diplazium esculentum, and study its amino acid profile. Response surface methodology is an affective statistical technique for optimizing complex processes. In this study Rotatable central composite design (RCCD) was employed with 5 levels. It is one of the commonly used statistical techniques for designing of experiments for food processes and food formulations.

Response surface methodology (RSM) has been shown to be an effective tool for optimizing processes [4,9-11]. Basically RSM relates product properties by using regression equations that describe interrelations between input parameters and product properties. RSM was used to optimize the conditions for an extruder, producing an amaranth-based snack food $[12,13]$. RSM was even used to analyze the effect of corn flour, green gram flour, xanthan, guar gum, arabic gum and carboxymethyl cellulose (CMC) on the sensory attributes (expansion ratio) of an extruded 
snack food and found that the responses were affected mostly by changing the levels of corn flour, green gram flour and guar gum and to a lesser extent by changing the levels of xanthan, arabic gum and CMC [10]. RSM was even used to optimize the ingredients and process conditions for preparing puri. Some good examples of the appropriate applications of this technique were tried on textured products for the optimization of complex products, properties and many process variables [1416].

On the other hand, genetic algorithm (GA) is one of the emerging trends in optimization of a complex objective function. This technique is based on genetic simulation of the biological evaluation process followed by crossover and mutation [17]. Natural selection principles and Darwin's species evolution theory are the basis for the development of genetic algorithm. Genetic algorithm is superior over other conventional techniques due to its less susceptibility to be stuck at local minima, requirement of minute knowledge of the process variables and capability of finding optimized conditions under the condition of large space [18]. Existence of living beings based on the competition for appropriate limited natural resources is the main principle of genetic algorithm (GA). Hence, it is one of the sturdier optimization techniques in terms of heftiness and easy customization. Now-a-days it is widely used in the field of food engineering and technology for the evaluation of optimization process [19]. The aim of the present study is to optimize the extraction of leaf protein concentrate from Diplazium esculentum by using response surface methodology (RSM) and genetic algorithm (GA).

\section{MATERIALS AND METHODS}

\section{Collection and Treatment of Samples}

The leaves of Diplazium esculentum were collected from Sonitpur district of Assam, India. The leaves were washed with running tap water followed by distilled water and weighed prior to pulping. Leaf protein concentrate was obtained by following the procedure of Fellows [20] with slight modification as illustrated in Figure 1. The leaf protein concentrate obtained was then hot air oven dried (Advantage Lab, Model: AL0105-100, Germany) for future chemical and functional property studies.

\section{Protein Extraction}

The leaves were ground with distilled water and subjected to $\mathrm{pH}$ adjustment with $1 \mathrm{~N}, \mathrm{HCl}$ and $1 \mathrm{~N}$, $\mathrm{NaOH}$, which was then subjected to ultrasound in bath sonicator (Bandelin Sonorex, Z659800, Berlin) inbuilt with temperature adjustment. The slurry derived after

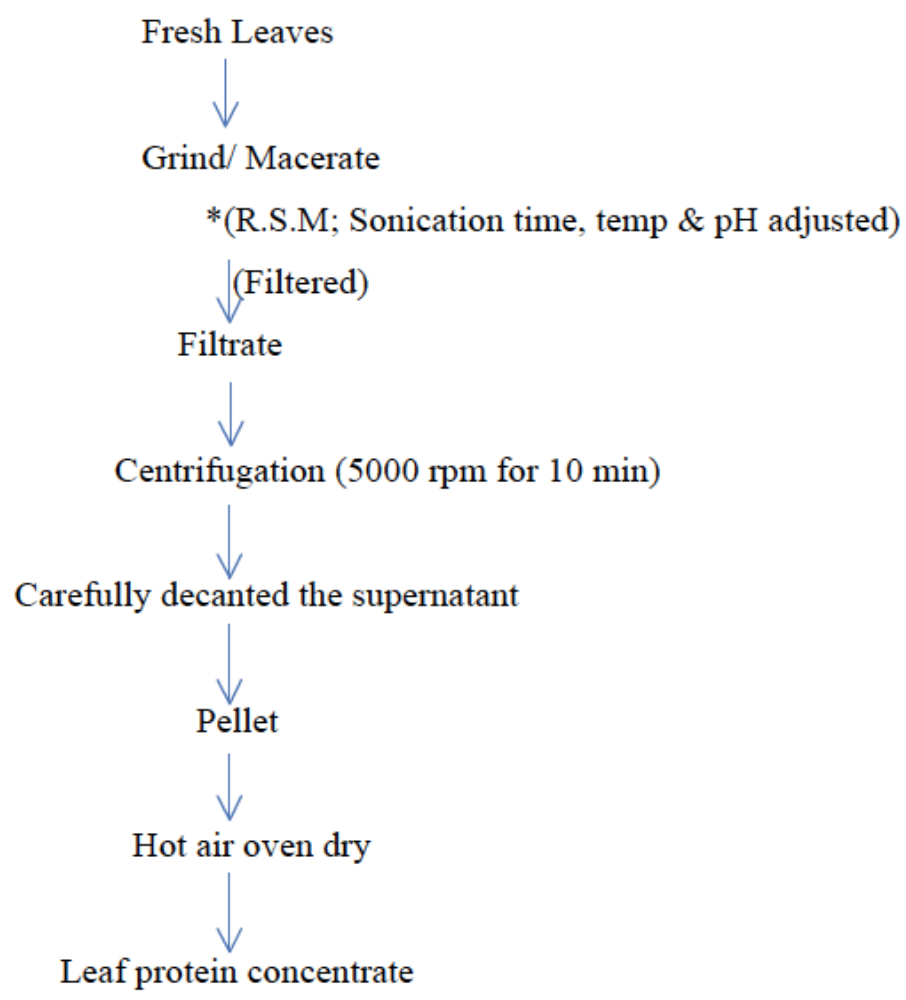

Figure 1: Flow chart of extraction of leaf protein concentrate with slight modification as adopted from Fellows [20]. 
grinding was then subjected to filtration with muslin cloth. The filtrate obtained was centrifuged at 5000 rpm. The residue obtained was the leaf protein concentrate which was hot air oven dried (Advantage Lab, Model: AL01-05-100, Germany) for $12 \mathrm{~h}$.

\section{Protein Determination}

The protein content of the leaf protein concentrate was determined by using Kjeldahl method [21] in Kjeldahl instrument [Pelican Kelplus Kes 12L (Digestion unit) + Kelplus classic DXVA(Distillation unit), India] and multiplying the nitrogen content of the sample with protein conversion factor of 6.25 .

\section{Experimental Design}

A rotatable central composite experimental design with 4 variables was used to study the response pattern and to determine optimum combination of the variables. The variables were $x_{1}$ (ultrasonic time), $\mathrm{x}_{2}$ (ultrasonic temperature), $\mathrm{x}_{3}(\mathrm{pH})$ and $\mathrm{x}_{4}$ (solvent concentration) on the response of protein yield $(Y)$. The process variables and their corresponding levels are shown in Table 1. The proposed equation for response was as follows:

$$
Y=\beta_{0}+\sum_{i=1}^{4} \beta_{i} X_{i}+\sum_{j=1}^{4} \beta i i X_{i}^{2}+\sum_{i=1}^{4} \sum_{j=1}^{4} \beta_{i j} X_{i} X_{j}
$$

Where $Y$ is measured response associated with each factor level combination, $\beta_{0}$ is an intercept and $\beta_{1}$ is regression coefficient computed from the experimental values of $Y$ and $X_{i}$ is the coded levels of independent variables the terms $X_{i} X_{J}$ and $X_{i}^{2}$ represents the interaction and quadratic terms respectively.

\section{Amino Acid Analysis by UHPLC}

Samples were hydrolyzed with $4 \mathrm{ml}$ of $6 \mathrm{~N} \mathrm{HCl}$. The solutions were sealed in tubes under Nitrogen and incubated in an oven at $110^{\circ} \mathrm{C}$ for $24 \mathrm{~h}$. Amino acids were determined by Ultra high-performance liquid chromatography (Thermo Scientific Dionex UHPLC, Model: Ultimate 3000 RSLC [22].

\section{Data Analysis}

Data were represented as means of 3 replicated determinations. The responses obtained from each set of experimental design were subjected to multiple nonlinear regressions analysis by using design expert version 6.0.11 (Stat-ease, Minneapolis, MN, USA). The fit of polynomial model equation and significances of regression coefficient were evaluated by the coefficient of determination $\left(R^{2}\right) \quad p$-value and lack of fit respectively. Model verification for checking the predicted response was done by finding percent of variation between the experimental and predicted values.

\section{RESULTS AND DISCUSSIONS}

The values of protein yield for different experimental combinations are presented in Table 2. For determining the effect of independent variables (ultrasonic time, ultrasonic temperature, $\mathrm{pH}$ an solvent concentration) on the response (Protein yield) statistical analysis was performed. Multiple regression analysis was done for the evaluation of the developed mathematical model between different factors and response. For estimating the behavior of the response as a function of independent variables, multiple regression coefficients were calculated. For determining the significance terms of the experimental data, ANOVA on each response variable was performed followed by the judgment of experimental data with the calculated F-value [23]. Adequacy of the model was checked and tested by lack of fit test, considering statistical parameters like fitted $R^{2}$, predicted $R^{2}$, PRESS and adequacy precision. On the basis of non- significant lack of fit ( $p>0.05$ ), higher $R^{2}$ value (closer to 1 ), low PRESS and higher adequacy precision value, the fitted model can be considered as the adequate one for predicting the mentioned response $[24,25]$.

Table 1: Processes Variables and their Corresponding Levels

\begin{tabular}{|c|c|c|c|c|c|c|}
\hline \multirow{2}{*}{ Independent variable } & \multirow{2}{*}{ Codified } & Uncodified & \multicolumn{4}{|c|}{ Level } \\
\cline { 3 - 7 } & & & $\mathbf{- 2}$ & $\mathbf{- 1}$ & $\mathbf{0}$ & $\mathbf{1}$ \\
\hline \hline Ultrasonic time $(\mathrm{min})$ & $\mathrm{x}_{1}$ & $\mathrm{X}_{1}$ & 2.5 & 15 & 27.5 & 40 \\
\hline Temperature $\left({ }^{\circ} \mathrm{C}\right)$ & $\mathrm{x}_{2}$ & $\mathrm{X}_{2}$ & 25 & 40 & 55 & 70 \\
\hline $\mathrm{pH}$ & $\mathrm{x}_{3}$ & $\mathrm{X}_{3}$ & 1 & 4 & 7.5 & 11 \\
\hline Solvent concentration $(\mathrm{ml})$ & $\mathrm{x}_{4}$ & $\mathrm{X} 4$ & 15 & 40 & 65 & 90 \\
\hline
\end{tabular}


Table 2: RCCD Experimental Design with Process Variables for Sonicated Treatment on Protein Yield

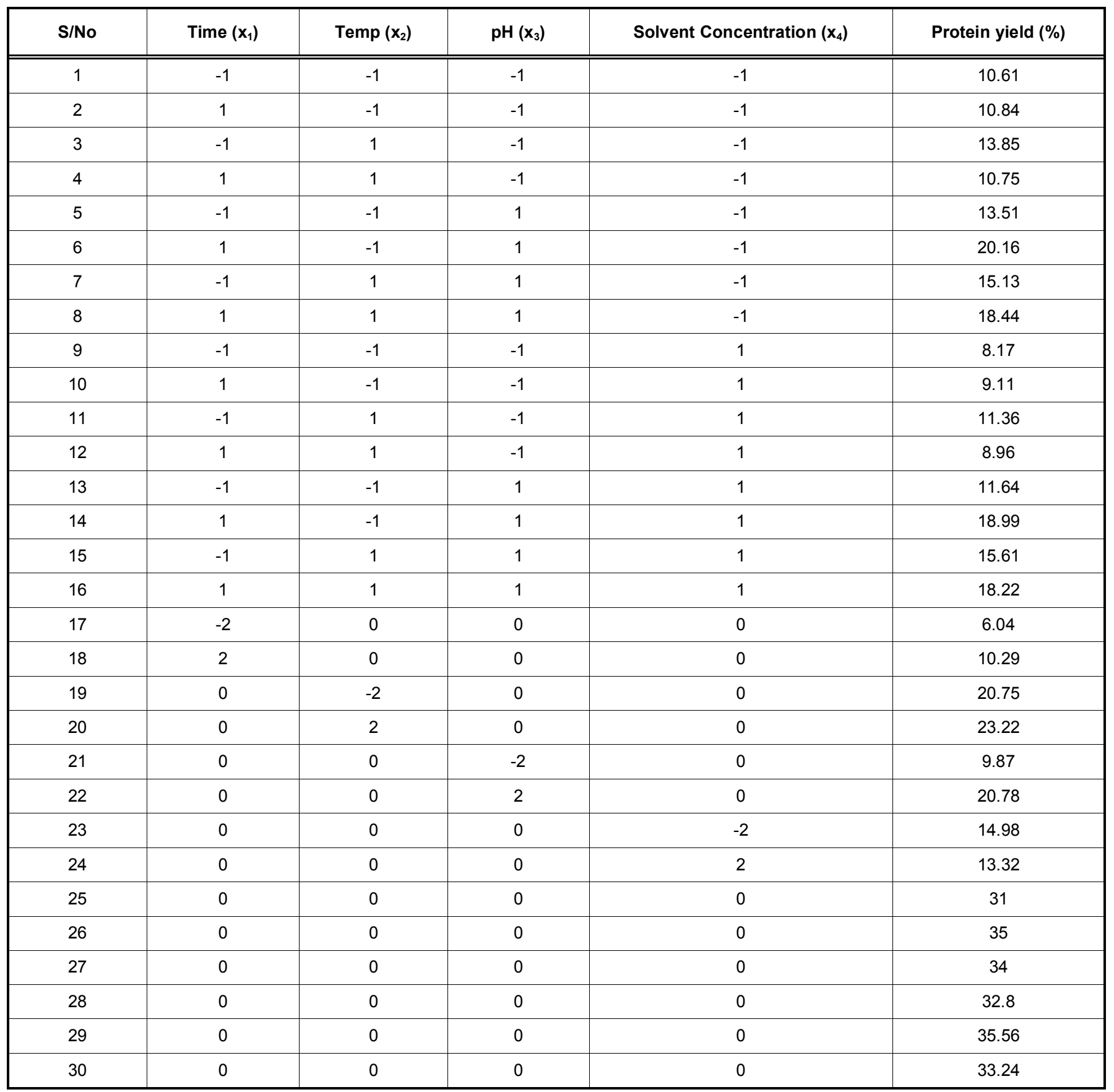

The values are mean of three replicates.

From Table 3, it can be observed that statistical parameters like probability $(p)$ values of the model, 4 independent variables, quadratic terms involved in the model were significant, whereas $\mathrm{x}_{1} \times \mathrm{X}_{2}$ and $\mathrm{x}_{1} \times \mathrm{x}_{3}$ were the only significant interaction terms. The lack of fit $(p>0.05)$ value of the model was non-significant with $p-$ value of 0.8409 , which implies accuracy of the model. The $R^{2}$ value of the model was 0.9887 , whereas the adjusted $R^{2}$ and predicted $R^{2}$ were 0.9782 and 0.9596 , respectively. On the basis of the above results, it can be conferred that the model is adequate and accurate enough for predicting the mentioned response.

The final equation in terms of coded factors was as follows:

Protein Yeild $=33.60+1.00 * \mathrm{x}_{1}+0.59^{*} \mathrm{x}_{2}+2.91^{*} \mathrm{x}_{3}-0.61^{*}$ $x_{4}-6.60^{*} \quad x_{1}{ }^{2}-3.14^{*} \quad x_{2}{ }^{2}-4.81^{*} \quad x_{3}{ }^{2}-5.10^{*} \quad x_{4}{ }^{2}-0.92^{*} \quad x_{1}$ * $x_{2}+1.52^{*} x_{1}{ }^{*} x_{3}+0.088^{*} x_{1}{ }^{*} x 4-0.19^{*} x_{2}{ }^{*} x_{3}+0.20^{*} x_{2}$ * $x_{4}+0.35^{*} x_{3}^{*} x_{4}$ 
Table 3: Analysis of Variance Showing the Linear, Quadratic, Interaction and Lack of Fit of the Response Variables

\begin{tabular}{|c|c|c|c|c|}
\hline \multirow{2}{*}{ Source of variation } & \multirow{2}{*}{ df } & \multicolumn{3}{|c|}{ Response variables } \\
\hline & & $\begin{array}{l}\text { Sequential sum of } \\
\text { squares }\end{array}$ & F-value & $p$ value \\
\hline Model & 14 & 2346.13 & 93.9 & $<0.0001^{* * *}$ \\
\hline $\mathrm{x}_{1}$ & 1 & 24.18 & 13.55 & $0.0022^{* * *}$ \\
\hline$x_{3}$ & 1 & 203.41 & 113.98 & $<0.0001^{* * *}$ \\
\hline $\mathrm{x}_{4}$ & 1 & 8.82 & 4.94 & $0.042^{*}$ \\
\hline $\mathrm{x}_{1}{ }^{2}$ & 1 & 1194.75 & 669.47 & $<0.0001^{* * *}$ \\
\hline$x_{2}^{2}$ & 1 & 271.28 & 152.01 & $<0.0001^{* * *}$ \\
\hline $\mathrm{x}_{1}{ }^{*} \mathrm{x}_{3}$ & 1 & 36.75 & 20.59 & $0.0004^{* * *}$ \\
\hline $\mathrm{x}_{1}{ }^{*} \mathrm{x}_{4}$ & 1 & 0.12 & 0.07 & 0.7955 \\
\hline $\mathrm{x}_{2}{ }^{*} \mathrm{X}_{3}$ & 1 & 0.6 & 0.33 & 0.5717 \\
\hline $\mathrm{x}_{2}{ }^{*} \mathrm{x}_{4}$ & 1 & 0.64 & 0.36 & 0.5594 \\
\hline $\mathrm{x}_{3}{ }^{*} \mathrm{X}_{4}$ & 1 & 2.01 & 1.13 & 0.3054 \\
\hline Residual & 15 & 26.77 & & \\
\hline Lack of Fit & 10 & 13.28 & 0.49 & 0.8409 \\
\hline Pure Error & 5 & 13.49 & & \\
\hline PRESS & 95.91 & & & \\
\hline
\end{tabular}

*Significant at $\mathrm{P} \leq 0.05$

${ }^{*}$ Significant at $\mathrm{P} \leq 0.01$

${ }^{* * *}$ Significant at $\mathrm{P} \leq 0.001$

Whereas the final equation in terms of actual factors was

Protein yeild $=-103.68582+2.395^{*} X_{1}+1.705^{*}$

$X_{2}+5.708^{*} X_{3}+0.969 * X_{4}-0.042^{*} X_{1}^{2}-0.014 * X_{2}^{2}$

$0.393^{*} X_{3}^{2}-0.008^{*} X_{4}^{2}-0.005^{*} X_{1}^{*} X_{2}+0.034643^{*} X_{1}^{*}$

$X_{3}+0.00028^{*} X_{1}{ }^{*} X_{4}-0.004^{*} X_{2}{ }^{*} X_{3}+0.001 *$

$\mathrm{X}_{2}{ }^{*} \mathrm{X}_{4}+0.004^{*} \mathrm{X}_{3}{ }^{*} \mathrm{X}_{4}$

\section{Effect of Interaction of Various Factors on Protein Yield}

Figure 2A illustrates the effect of time and temperature on protein yield. It can be observed that the protein yield increases with sonication temperature and time. Similar findings were observed on sonication time for the extraction of phenolic compounds from coconut shell [26]. Similar findings for extraction temperature in the extraction of phytic acid from peanut seeds $[26,27]$. The increase in protein yield with the increase in sonication time might be accredited due to the increase in mass transfer process with the rising trend of sonication time, whereas increase in temperature leads to breakdown of cell wall of the Diplazium esculentum plant, which resulted in maximum yield of protein.

The effect of $\mathrm{pH}$, time and temperature on protein yield is presented in Figure $\mathbf{2 B}$ and $\mathbf{D}$. In both cases, protein yield increases with the increase of $\mathrm{pH}$, 

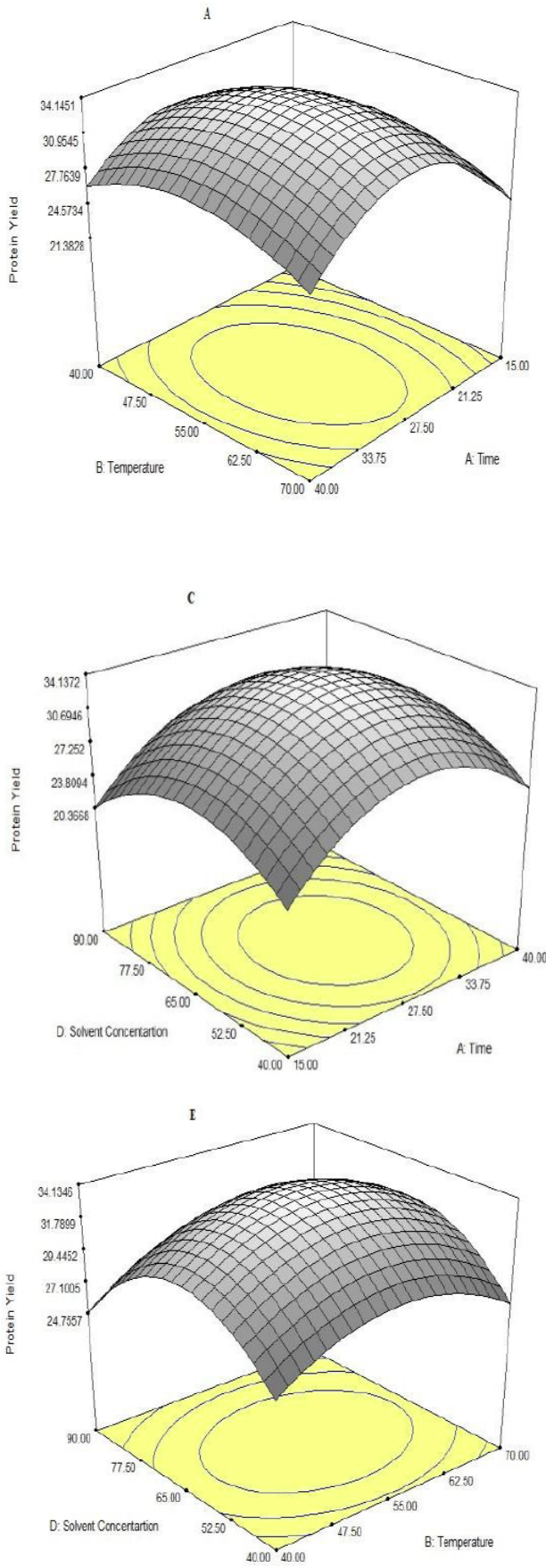
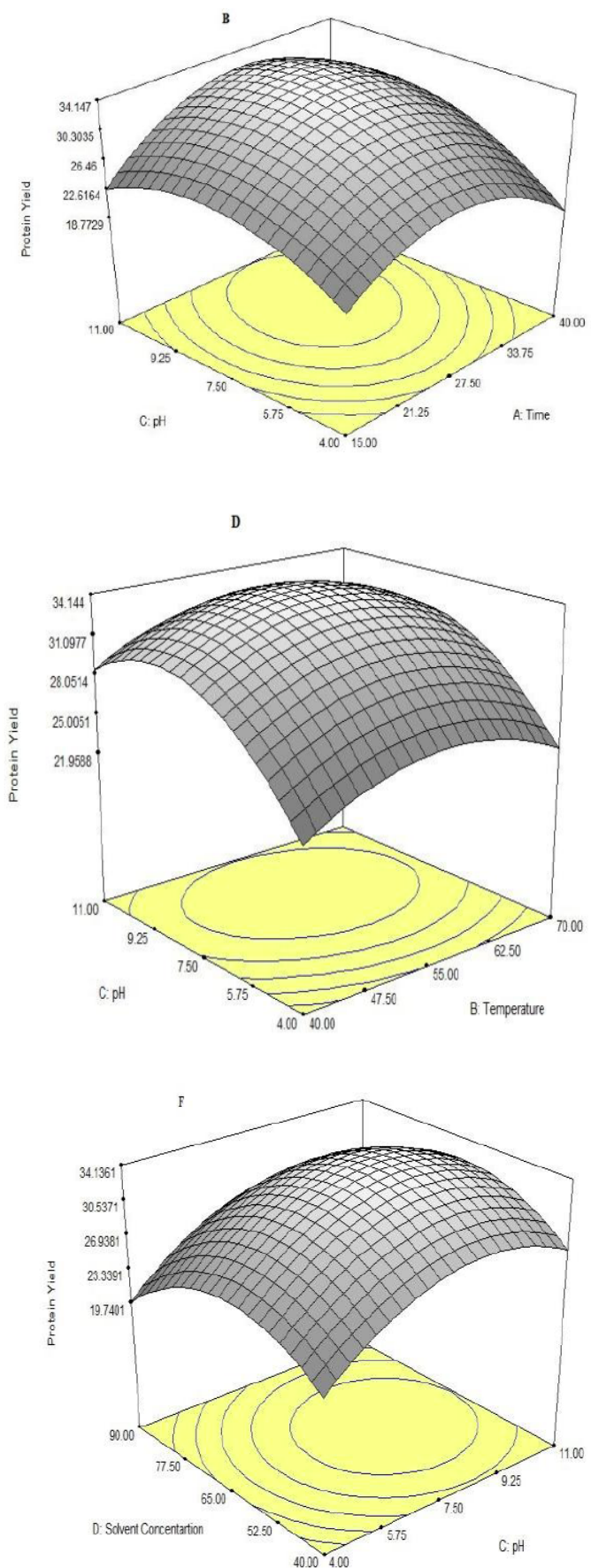

Figure 2: Variation of protein yield against different processing factors.

A) Interaction effect of temperature and time on protein yield B) Interaction effect of $\mathrm{pH}$ and time on protein yield C) Interaction effect of solvent concentration and time on protein yield $\mathbf{D}$ ) Interaction effect of $\mathrm{pH}$ and temperature on protein yield $\mathbf{E}$ ) Interaction effect of solvent concentration on protein yield $\mathbf{F}$ ) Interaction effect of solvent concentration and pH on protein yield.

sonication time and temperature respectively. This work can be explained with the works of Irakoze and Sindayigaya [28] where they worked on the optimization of Malted Sorghum. The increase in protein yield with the increasing concentration of $\mathrm{pH}$ is due to the fact that protein denaturation decreases with the rise in $\mathrm{pH}$ value that resulted in higher amount of protein yield.
Figure 2C and $\mathbf{E}$ depict the effect of solvent concentration, time and temperature on protein yield. It can be observed that solvent concentration with the increase of sonication time or temperature increases up to a certain point and then decreases. The increase in protein yield with the increasing concentration of solvent up to a certain point might be due to effective swelling of the leaves, resulting in increased surface 
area for solute-solvent contact. But after certain period of time, as the bound water is released from the swelled leaves, the concentration of the solution starts decreasing. As a result of which there is no significant effect of solvent concentration on the protein yield. Similar findings were observed on the effect of solvent concentration for the extraction of rebaudioside $A$ from Stevia leaves [29].

Figure $2 \mathbf{F}$ reveals the effect of $\mathrm{pH}$ and solvent concentration on protein yield and it increases with the increase in $\mathrm{pH}$ as mentioned earlier, but solvent concentration shows rising effect on the protein yield up to a certain point followed by final decrease in the protein yield upon further increase of its concentration.

\section{Optimization Using Genetic Algorithm and Model Verification}

The optimum results can be obtained by using several methods like overlaying of contour plots i.e. graphical method and combining all the responses into one measurement i.e. desirability function [30]. In this study, independent variables were optimized numerically using statistical software Design Expert for RSM (version 6.0.11, Stat-Ease, Inc 2021, East Hanuepin Ave., Suite 480, Minneapolis, MN 55413) and MATLAB-R2012a for genetic algorithm. These two optimization processes were compared on the basis of highest desirability factor. From the numerical analysis of response surface methodology, it was observed that $28.84 \mathrm{~min}$ of sonication time, $56{ }^{\circ} \mathrm{C}$ temperature, 8.61 $\mathrm{pH}$ and $63.86 \mathrm{ml}$ of solvent are the best condition for an optimum protein yield of $34.15 \%$. In this case, highest desirability for the optimization process was 0.952 .

The condition and constraints of genetic algorithm is given below:

\section{Maximization of the following Objective Function}

Protein Yeild $=-103.68582+2.395^{*} X_{1}+1.705$ *

$\mathrm{X}_{2}+5.708^{*} \mathrm{X}_{3}+0.969^{*} \mathrm{X}_{4}-0.042^{*} \mathrm{X}_{1}^{2}-0.014^{*} \mathrm{X}_{2}{ }^{2}$

$0.393^{*} X_{3}{ }^{2}-0.008^{*} X_{4}{ }^{2}-0.005^{*} X_{1}{ }^{*} X_{2}+0.034643^{*} X_{1}{ }^{*}$

$X_{3}+0.00028^{*} X_{1}{ }^{*} X_{4}-0.004^{*} X_{2}{ }^{*} X_{3}+0.001 *$

$\mathrm{X}_{2}{ }^{*} \mathrm{X}_{4}+0.004^{*} \mathrm{X}_{3}{ }^{*} \mathrm{X}_{4}$

Where, $\mathrm{X}_{1=\text { Time }}$

$$
\begin{aligned}
& \mathrm{X}_{2=} \text { Temperature } \\
& \mathrm{X}_{3}=\mathrm{pH} \\
& \mathrm{X}_{4}=\text { Solvent concentration }
\end{aligned}
$$

Ranges of Process parameters

$$
\begin{aligned}
& 15 \leq X_{1} \leq 40 \\
& 40 \leq X_{2} \leq 70 \\
& 4 \leq X_{3} \leq 11 \\
& 40 \leq X_{4} \leq 90
\end{aligned}
$$

The main parameters in this optimization process were population size, mutation rate, crossover rate and number of generations, respectively (Table 4). The optimized result obtained by using genetic algorithm and RSM is shown in Table 5. From the results, it can be observed that the desirability of the optimized result obtained from genetic algorithm is comparatively more than response surface methodology. So, for predicting the optimized process parameters with maximum protein yield, genetic algorithm gave better results. Model verification was done on the basis of per cent of variation between the predicted and actual protein yield. From Table 6 it can be observed that the per cent of variation between the actual and predicted protein

Table 4: Conditions for Genetic Algorithm (G.A)

\begin{tabular}{|c|c|c|c|c|}
\hline SI No & Population size & Mutation rate & Crossover rate & Number of generations \\
\hline \hline 1. & 40 & 1.0 & 0.8 & 1000 \\
\hline
\end{tabular}

Table 5: Optimized Result Obtained by Using Genetic Algorithm (GA) and Response Surface Methodology (RSM)

\begin{tabular}{|c|c|c|c|c|c|c|c|}
\hline SI. No & $\begin{array}{c}\text { Name of } \\
\text { optimization } \\
\text { technique }\end{array}$ & $\begin{array}{c}\text { Time } \\
(\mathbf{m i n})\end{array}$ & $\begin{array}{c}\text { Temperature } \\
\left({ }^{\circ} \mathbf{C}\right)\end{array}$ & pH & $\begin{array}{c}\text { Solvent } \\
\text { concentration } \\
(\mathbf{m l})\end{array}$ & $\begin{array}{c}\text { Protein yield } \\
(\%)\end{array}$ \\
\hline \hline 1. & GA & 21.12 & 56.88 & 7.59 & 66.2 & 33.79 \\
\hline 2. & RSM & 28.84 & 56.00 & 8.61 & 63.86 & 34.15 & 0.952 \\
\hline
\end{tabular}


Table 6: Validation of the Optimized Result

\begin{tabular}{|c|c|c|}
\hline & Response obtained from GA & Response obtained from RSM \\
\hline \hline Predicted value & Protein yield & 34.15 \\
\hline Actual value & 33.79 & $33.29 \pm 0.18^{\mathrm{a}}$ \\
\hline$\%$ Variation & $33.89 \pm 0.29^{\mathrm{a}}$ & 2.51 \\
\hline Mean difference & 0.29 & 0.86 \\
\hline
\end{tabular}

a signifies standard deviation.

yield was less in case of GA as compared to RSM. Comparative results (Tables 5 and $\mathbf{6}$ ), revealed that GA is a superior optimization technique over RSM.

\section{Evaluation of Amino Acid Composition}

The amino acid composition in the leaf protein concentrate of Diplazium esculentum are presented in Table 7 and Figure 3. The total amino acid present in Diplazium esculentum is $210.81 \mathrm{mg} / \mathrm{g}$ which are comparatively high with respect to Telferia occidentalis and Amaranthus hybridus [31]. In the present study total amount of essential amino acid is $48.36 \mathrm{mg} / \mathrm{g}$ which is also high when compared with Telferia occidentalis and Amaranthus hybridus [31]. The total amount of sulphur containing amino acid (cysteine and methionine) was found to be $62.56 \mathrm{mg} / \mathrm{g}$ which are also

Table 7: Amino Acid Compositions in the Leaves of Diplazium esculentum

\begin{tabular}{|c|c|}
\hline Amino acids & Diplazium esculentum $(\mathbf{m g} / \mathbf{g})$ \\
\hline \hline Lysine & $2.73 \pm 0.12$ \\
\hline Threonine & $6.08 \pm 0.27$ \\
\hline Cysteine & $41.71 \pm 0.18$ \\
\hline Valine & $2.40 \pm 0.31$ \\
\hline Methionine & $20.85 \pm 0.23$ \\
\hline Isoleucine & $6.18 \pm 0.05$ \\
\hline Leucine & $7.05 \pm 0.13$ \\
\hline Tyrosine & $6.18 \pm 0.07$ \\
\hline Phenylalanine & $8.32 \pm 0.03$ \\
\hline Histidine & $1.8 \pm 0.04$ \\
\hline Arginine & $53.6 \pm 0.11$ \\
\hline Glycine & $1.27 \pm 0.02$ \\
\hline Alanine & $3.90 \pm 0.03$ \\
\hline Glutamine & $46.0 \pm 0.22$ \\
\hline Asparagine & $2.73 \pm 0.24$ \\
\hline
\end{tabular}

Results are expressed as mean of three replications \pm standard deviation. high compared to $58 \mathrm{mg} / \mathrm{g}$ recommended for infants [32]. Cysteine and methionine residue functions in the catalytic cycle of many enzymes by forming disulphide bonds that contribute in protein structure however the specific function of methionine is not known but a variety of oxidants react with methionine to form methionine sulphoxide which in turn serves as an efficient oxidant scavenger [33]. Amino acids such as glutamine and argenine are also present in high concentration in this particular leaf protein concentrate of Diplazium esculentum, which in turn are reported to have health benefitting effects. Glutamine is reported to be present as free amino acid available for circulation and is also present in the intracellular pools. It acts as a precursor for the synthesis of aminoacids, proteins, nucleotides and many biologically important molecules and also in the degradation of skeletal muscles and stimulating glycogen synthesis in the liver [34]. On the other hand arginine improves blood circulation, strengthens immune system, accelerates rate of healing of wounds, improves the burning of excess of fats in the body, reduces cholesterol levels from blood and acts as a biological precursor of nitrous oxide (NO) [35].

\section{CONCLUSIONS}

In conclusion RSM, GA and UHPLC analysis established Diplazium esculentum to be a good candidate of protein source, which is mostly neglected, and ultrasound served the extracting leaf protein concentrate in maximized amount. The optimized conditions for response surface methodology (RSM) were observed to be $28.84 \mathrm{~min}$ of sonication time, 56.0 ${ }^{\circ} \mathrm{C}$ temperature, $8.61 \mathrm{pH}$ and $63.86 \mathrm{ml}$ of solvent with a desirability value of 0.952 , whereas for genetic algorithm, the optimum results were observed to be $21.12 \mathrm{~min}$ of sonication time, $56.88{ }^{\circ} \mathrm{C}$ temperature, $7.59 \mathrm{pH}$ and $66.2 \mathrm{ml}$ of solvent with a desirability value of 1.00 . In this case the optimum protein yield was $33.79 \%$, whereas for RSM, it was $34.15 \%$, respectively. 


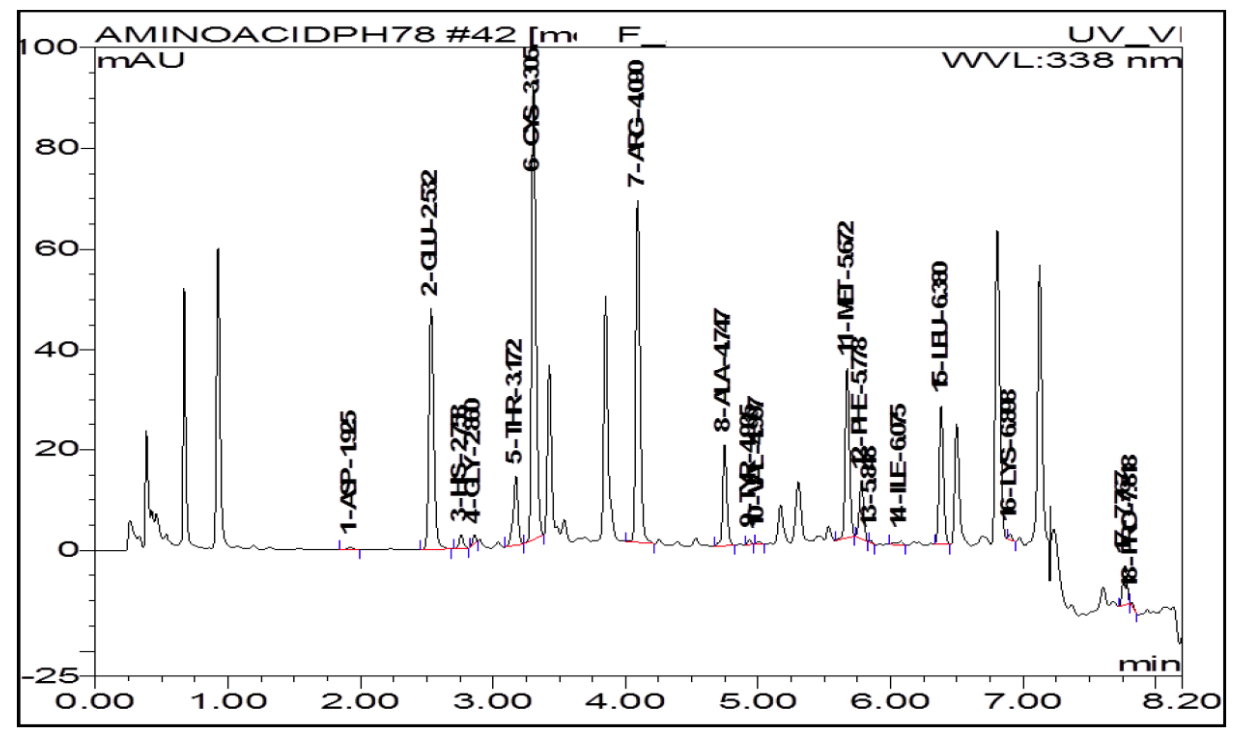

Figure 3: UHPLC chromatogram of LPC from (Diplazium esculentum).

Model verification for checking the predicted response was done by finding percent of variation between the actual and predicted values. The percent of variation in case of GA was less than RSM. Hence, it can be concluded that genetic algorithm (GA) is superior over response surface methodology (RSM) in order to find out optimized condition of maximum protein yield. LPC obtained was later used to study the functional properties.

\section{ACKNOWLEDGEMENT}

Financial support received from Ministry of Food Processing Industries (MoFPI) through Science and Engineering Research Board (SERB), Department of Science and Technology (Govt. of India), New Delhi, India is duly acknowledged.

\section{REFERENCES}

[1] Copeland EB. Edible ferns. Amer Fern J 1942; 32: 121-6. http://dx.doi.org/10.2307/1545216

[2] Kumar GN. Studies on pathological effects of linguda (Diplazium esculentum, R.) in laboratory rats and guinea pigs. Indian J Vet Pathol 2004; 28(2): 149.

[3] Tongco JVV, Ronald AP, Villaber RM, Ramon AR. Nutritional and phytochemical screeningand total phenolic and flavonoid content of Diplazium sculentum(Retz.) from Philippines. J Chem Pharm Res 2014; 6(8): 238-42.

[4] Zhu, Jianfei, Fu. Optimization of ultrasound-assisted extraction process of perilla seed meal proteins. Food Sci Biotechnol 2012; 21(6): 1701-6. http://dx.doi.org/10.1007/s10068-012-0226-7

[5] Gerloff, Iracema HL, Mark AS. Leaf proteins as foodstuffs, amino acid composition of leaf protein concentrates. J Agric Food Chem 1965; 13(2): 139-43. http://dx.doi.org/10.1021/jf60138a012

[6] Beulajosepin ED, Mungikar AM. Biochemical analysis of leaf protein concentrate prepared from selected plant species of Tamil Nadu. Int J Pharm Res Dev 2013; 5(3): 7-14.
[7] Govindaraju, K. Studies on the preparation and characterization of protein hydrolysates from groundnut and soybean isolates. PhD dissertation, University of Mysore, India 2003.

[8] Jambrak AR, Vesna L, Timothy J, Mason GK, Marija B. Physical properties of ultrasound treated soy proteins. J Food Eng 2009; 93(4): 386-93.

http://dx.doi.org/10.1016/j.jfoodeng.2009.02.001

[9] Wani AA, Sogi DS, Grover L, Saxena DC, Effect of temperature, alkali concentration, mixing time and meal/solvent ratio on the extraction of watermelon seed proteins-A response surface approach. Biosystems Eng 2006; 94(1): 67-73.

http://dx.doi.org/10.1016/j.biosystemseng.2006.02.004

[10] Vatsala CN, Saxena CD, Rao HP. Optimization of ingredients and process conditions for the preparation of puri using response surface methodology. Int J Food Sci Technol 2001; 36(4): 407-14.

http://dx.doi.org/10.1046/j.1365-2621.2001.00474.x

[11] Thakur S, Saxena DC. Formulation of extruded snack food (gum based cereal-pulse blend): optimization of ingredients levels using response surface methodology. LWT-Food Sci Technol 2000; 33(5): 354-61.

http://dx.doi.org/10.1006/fstl.2000.0668

[12] Colonna P, Doublier JL, Melcion JP, Monredon F De, Mercier C. Extrusion cooking and drum drying of wheat starch I. Physical and macromolecular modifications. Cer Chem 1984; 61(6): 538-43.

[13] Chavez, Jauregui RN, Silva EMP, Areas JAG, Extrusion cooking process for amaranth (Amaranthus caudatus L.) J Food Sci 2000; 65(6): 1009-15. http://dx.doi.org/10.1111/j.1365-2621.2000.tb09408.x

[14] Onwulata $\mathrm{Cl}$, Konstance RP, Strange ED, Smith PW, Holsinger $\mathrm{VH}$. High-fiber snacks extruded from triticale and wheat formulations. Cer Foods World 2000; 45(10): 470-3.

[15] Rosell CM, Rojas JA, Barber De, Benedito C. Influence of hydrocolloids on dough rheology and bread quality. Food Hydrocolloids 2001; 15(1): 75-81.

http://dx.doi.org/10.1016/S0268-005X(00)00054-0

[16] Latharn MC. Human Nutrition in the developing world. Food and Agricultural organization of the United Nations. Rome, Italy 1997; 522.

[17] Mohebbi M, Shahidi F, Fathi M, Ehtiati A, Noshad M Prediction of moisture content in preosmosed and ultrasounded dried banana using genetic algorithm and 
neural network. Food and Bioproducts Proc 2011; 9(4): 362-6.

http://dx.doi.org/10.1016/j.fbp.2010.08.001

[18] Morimoto T, Sablani SS, Rahman MS, Datta AK, Mujumdar AS. Genetic algorithm. In Food and Bioprocess Modeling Techniques; CRC Press: New York 2006. http://dx.doi.org/10.1201/9781420015072.ch13

[19] Khawas P, Dash KK, Das AJ, Deka SC Modeling and Optimization of the Process Parameters in Vacuum Drying of Culinary Banana (Musa $A B B$ ) Slices by Application of Artificial Neural Network and Genetic Algorithm. Drying Technol 2015; 34: 491-503. http://dx.doi.org/10.1080/07373937.2015.1060605

[20] Fellows PJ. Village scale leaf fraction in Ghana. Tropical Sci 1987; 27: 77-84.

[21] AOAC Official Methods of Analysis of AOAC Intl. Method 979.09. Association of Official Analytical Chemists, 1994.Washington, DC, USA.

[22] Manuel A, Jose LN, Julio G, Eduardo V. Amino acid analysis by high-performance liquid chromatography after derivatization with diethyl ethoxymethylene malonate. J Chromatog A 1992; 591(1): 181-6.

[23] Mitra J, Shrivastava SL, Rao PS. Process optimisation of vacuum drying of onion slices. Czech J Food Sci 2011; 29(6): 586-94.

[24] Corzo O, Bracho N, Vasquez A, Pereira A. Optimization of a thin layer drying process for coroba slices. J Food Eng 2008; 85(3): 372-80. http://dx.doi.org/10.1016/j.jfoodeng.2007.07.024

[25] Erbay Z, Icier F. Optimization of hot air drying of olive leaves using response surface methodology. J Food Eng 2009; 91(4): 533-41.

http://dx.doi.org/10.1016/j.jfoodeng.2008.10.004

[26] Rodrigues S, Gustavo AS, Pinto, Fabiano AN, Fernandes. Optimization of ultrasound extraction of phenolic compounds from coconut (Cocos nucifera) shell powder by response surface methodology. Ultrasonic Sonochem 2008; 15(1): 95100.

http://dx.doi.org/10.1016/j.ultsonch.2007.01.006
[27] NQ D, Dao Dta MN, Different extraction methods to obtain the highest phytic acid yield from peanut seeds. Int J Biolog Pharm and Allied Sci 2013; 2(12): 2378-99.

[28] Claver, Irakoze P, Sindayigaya E. Optimization of malted sorghum protein extraction by response surface methodology. J Food Sci Technol Nepal 2013; (6): 53-8. http://dx.doi.org/10.3126/jfstn.v6i0.8260

[29] Gasmalla M, Abdalbasit A, Ruijin Y, Abubakr M, Xiao H, Fayin $\mathrm{Y}$. Influence of sonication process parameters to the state of liquid concentration of extracted rebaudioside $A$ from Stevia (Stevia rebaudiana bertoni) leaves. Arab J Chem 2014 (In Press). Available online 11 July 2014. http://dx.doi.org/10.1016/j.arabjc.2014.06.012

[30] Park SH, Park JU. Simultaneous optimization of multiple response using weighted desirability function. J Kor Soc Quality Mangm 1997; 25: 56-68.

[31] Emmanuel IA, Folasade OO. Chemical composition and functional properties of leaf protein concentrates of Amaranthus hybridus and Telferia occidentalis. Agr Biol J North Amer 2011; 2: 499-511. http://dx.doi.org/10.5251/abjna.2011.2.3.499.511

[32] Joint FA. Energy and Protein Requirements: Report of a Joint $\mathrm{FAO} / \mathrm{WHO} / \mathrm{UNU}$ Expert Consultation. In Technical Report Series World Health Organization 1985; (724).

[33] Rodney LL, Laurent M, Barbara S, Barlett E, Stadman R, Methionine residues as endogenous antioxidants in proteins. Proc Nat Acad Sci USA 1996; 93(26): 15036-40. http://dx.doi.org/10.1073/pnas.93.26.15036

[34] Smith RJ, Glutamine metabolism and its physiological importance. J Parent Enter Nut 1990; 14(4): 40S-4S. http://dx.doi.org/10.1177/014860719001400402

[35] Williams JZ, Abumrad N, Barbul A. Effect of specialized amino acid mixture on human collagen deposition. Annal Surg 2002; 236(3): 369-75. http://dx.doi.org/10.1097/00000658-200209000-00013

\section{DOI: http://dx.doi.org/10.6000/1927-3037.2016.05.03.5}

(C) 2016 Saha et al.; Licensee Lifescience Global.

This is an open access article licensed under the terms of the Creative Commons Attribution Non-Commercial License (http://creativecommons.org/licenses/by-nc/3.0/) which permits unrestricted, non-commercial use, distribution and reproduction in any medium, provided the work is properly cited. 